\title{
Evaluation of the Regional Ecological Environment in Central China Based on the Ecological Footprint Model
}

\author{
Wang Jun ${ }^{1}$, Wang Jinxin ${ }^{2, *}$, Li Yongsheng ${ }^{3}$ and Wang Mingchun ${ }^{1}$ \\ ${ }^{1}$ College of Forestry, Northwest A\&F University, Yangling 712100, China; ${ }^{2}$ College of Natural Resources and Envi- \\ ronment, Northwest $A \&$ \& F University, Yangling 712100, China; ${ }^{3}$ College of Forestry, Henan Agricultural University, \\ Zhengzhou, Henan 450002, China
}

\begin{abstract}
The ecological footprint is a quantitative biophysical method commonly used to evaluate the status of regional ecological environment and the degree of sustainable development. In this paper, the concept and calculation process of the ecological footprint are introduced by taking a county located in central China as example. Computational analysis and empirical research of the region's ecological footprint is carried out. It turns out that the per-capita ecological footprint and per-capita Biocapacity of the county is $1.207382 \mathrm{hm}^{2}$ and $0.506497 \mathrm{hm}^{2}$ respectively, so the per-capita ecological deficit of $0.700885 \mathrm{hm}^{2}$ appears, which shows that the pressure put by the social development and human activities have exceeded the Biocapacity of the county and the status of the development is unsustainable. Therefore, on the basis of our study, proposals and measures are raised in the end to build a more sustainable development economy.
\end{abstract}

Keywords: Biocapacity, county ecological environment, ecological environment evaluation, ecological footprint.

\section{INTRODUCTION}

With the rapid development of the social industrialization and social urbanization, the excessive exploitation of natural resources and emissions of pollutants result in a series of environment problems, such as reduce of arable land, decrease of forest coverage, serious soil erosion, aggravating desertification, degradation of grassland, air pollution and so on. To make the development reasonable and sustainable, the sustainable development concept is developed which suggests that the progress and potential of the regional development are not only indicated by the speed of economic growth but also the resource and environment costs sacrificed. Hence, it is necessary to evaluate the regional ecological environment, which may be a scientific basis and reference for the sustainable development with economic growth and environment protection combined.

As the basic administrative unit of china, the land area, population and total economic output of the county account for about $90 \%, 80 \%$ and $60 \%$ of these of the whole country respectively, so the county plays an important role in the national economy and social structure, and the development of the county is the basement of the socio-economic development. However, compared with the development of major cities, the developments of the county obviously lag behind in china. Meanwhile, the problems of natural resources shortage, increasing environment pollution are also encountered. Therefore, to explore the application of ecological footprint theory and the implementation of sustainable development strategy, it is essential to evaluate the ecological environment status of the county [1-5].
In this paper, to analyze the ecological environment status and economic development of Ru yang in Henan province, ecological environment research of the region is conducted by the ecological footprint theory, of which the theoretical model and accounting standards are developed by William Rees in 1992 and widely applied to evaluate the regional ecological environment. The result may be a guideline for the social development and environment protection of the entire county in the central china.

\section{THE OVERVIEW OF RUYANG COUNTY}

$\mathrm{Ru}$ yang county, located in east longitude of $112^{\circ} 8^{\prime}$ $112^{\circ} 38^{\prime}$, and north latitude of $33^{\circ} 49^{\prime}-34^{\circ} 21^{\prime}$, the western Henan province of central china, across the Yellow and Huai River basin, is one of 25 key forestry counties in Henan province. The county-wide total area is about $132807.8 \mathrm{hm}^{2}$, and the total population is 473,010 , of which the agricultural population is 407 thousands and the non-agricultural population is 66 thousands. The climate is warm temperate continental monsoon climate with abundant sunshine, four distinct seasons, annual average sunshine hours of $2177.3 \mathrm{~h}$, annual average temperature of $14^{\circ}$, annual average rainfall of $690 \mathrm{~mm}$, and annual average frost-free period 213 days. Three types of geomorphologies are contained in the county with low-lying north south high: mountain, hill and plain. Due to the abundant mineral resources, the county regional economy is developed in a road of new-type industrialization relying on the rich non-ferrous metals. By 2010, the percentage that the industrial added value accounts for the regional GDP increases to be $47 \%$, and contributes more than half of the economic growth, which indicates the industry becomes to be dominant in the regional economy. 
Table 1. The equivalence factor of different categories of spaces.

\begin{tabular}{|c|c|c|c|c|c|}
\hline $\begin{array}{c}\text { Type of Ecological } \\
\text { Footprint }\end{array}$ & $\begin{array}{c}\text { Arable and Built-up } \\
\text { Land }\end{array}$ & $\begin{array}{c}\text { Forest and Fossil } \\
\text { Energy Land }\end{array}$ & Pasture & $\begin{array}{c}\text { Non-Productive } \\
\text { Land }\end{array}$ \\
\hline \hline Equivalence factor & 2.8 & 1.1 & 0.5 & 0.2 & 0.12 \\
\hline
\end{tabular}

Table 2. The yield factor of different categories of Bioproductive area.

\begin{tabular}{|c|c|c|c|c|c|c|}
\hline $\begin{array}{c}\text { Type of Ecologi- } \\
\text { cal Footprint }\end{array}$ & $\begin{array}{c}\text { Arable and Built- } \\
\text { up Land }\end{array}$ & Forest & Pasture & Fisheries & Fossil Fuel Land & $\begin{array}{c}\text { Non-Productive } \\
\text { Land }\end{array}$ \\
\hline \hline Yield factor & 1.66 & 1.1 & $0 . .19$ & 0.1 & 0.61 & 1 \\
\hline
\end{tabular}

\section{THE ECOLOGICAL FOOTPRINT}

The ecological model is a concept and method used to evaluate the pressure imposed by human on natural capital and offering real bio capacity within a given region or country on the basis of biophysical measure, which is developed by William Rees, a Canadian economist, in 1992, and then modified by doctor Wackernagel, his student, in 1996. The ecological footprint of a region with certain population is commonly defined as the Bioproductive area needed to produce the materials for human's consumption and assimilate the waste production.

The calculation of the ecological footprint is based on the two basic facts: 1) It is possible to track the annual amounts of resources consumed and wastes generated by countries; 2) The majority of these resource flows can be related to the Bioproductive area necessary for their regeneration and the assimilation of their waste [2].

From the demand side, the ecological footprint is represented by the Bioproductive area required for the material and resource consumption. From the supply side, the Biocapacity is shown by the Bioproductive area the region can provide. All mutually exclusive resource and wasteassimilating demand can be aggregated to six different Bioproductive area: arable land, pasture, forest land, built-up land, fossil energy land and fisheries. The evaluation of the regional environment and sustainable development status is conducted by the comparison of the two sides.

\subsection{The Calculation of Ecological Footprint}

As mentioned above, the Bioproductive area on the earth is divided into six categories: arable land, pasture, forest land, built-up land, fossil fuel land and fisheries. It is clear that the biological production capacity of each category of area differs greatly. Therefore, to aggregate the different categories of space to a total footprint and make the calculation results be comparable, the area of each category of area is multiplied by a 'equivalence factor', which represents the world average potential productivity of a given Bioproductive area relative to the world average potential productivity of all Bioproductive areas and will relate the different categories of area to the footprint in global hectares. Then the regional ecological footprint will be obtained by the weighted summation of the Bioproductive areas by (1). The equivalence factors utilized in our study are shown in Table $1[2,3]$. Meanwhile, the Non-productive land including the desert, saline land, tideland and so on, are not counted in the ecological footprint calculation, for they are unable to provide human consumption products directly. However, these lands should be contained when the Biocapacity is assessed due to the ecological value.

$\mathrm{EF}=\mathrm{N}^{*} \mathrm{ef}=\mathrm{N} \sum_{i=1}^{n} A_{\mathrm{i}}=\mathrm{N}^{*} \sum_{i=1}^{n}\left(\mathrm{r}_{\mathrm{i}} \mathrm{c}_{\mathrm{i}} / \mathrm{p}_{\mathrm{i}}\right)$

In which $\mathrm{EF}$ is the total ecological footprint, $\mathrm{N}$ is the population, ef is the per-capita ecological footprint, i represents different types of consumption and resource, $A_{i}$ is the per-capita ecological footprint aggraded from each type of resource consumption, $\mathrm{n}$ is the number of the consumption items, $r_{i}$ is the equivalence factor of different Bioproductive areas, and $\mathrm{c}$ is the per-capital consumption of all goods while $\mathrm{c}_{\mathrm{i}}$ is the per-capital consumption of each kind of goods $(\mathrm{kg})$. $\mathrm{p}$ and $\mathrm{p}_{\mathrm{i}}$ represent the world average production capacity of all goods and the world average yield of each goods or services $\left(\mathrm{kg} / \mathrm{hm}^{2}\right)$ respectively.

\subsection{The Calculation of Biocapacity}

The Biocapacity is embodied by the total Bioproductive area in the county. It is no doubt that the production capacity of the same land in different regions varies considerably, so the Bioproductive area of different categories have to be multiplied by the equivalence factor and yield factor shown in Table 2 [2], which informs about the category's relative yield (measured in primary or green biomass productivity) as compared with the world-average area. The Biocapacity is calculated by (2).

$\mathrm{EC}=\mathrm{N}^{*} \mathrm{ec}=\mathrm{N}^{*} \sum_{j=1}^{n}\left(\mathrm{a}_{\mathrm{j}} \mathrm{r}_{\mathrm{j}} \mathrm{y}_{\mathrm{j}}\right)=\mathrm{N}^{*} \sum_{j=1}^{n}\left(\mathrm{E}_{\mathrm{j}} / \mathrm{P}_{\mathrm{j}}\right) \mathrm{r}_{\mathrm{j}} \mathrm{y}_{\mathrm{j}}$

where EC is represented as the regional Biocapacity, $\mathrm{N}$ is the population, ec is the per-capital Biocapacity, $\mathrm{j}$ represents different categories of Bioproductive area in the county, $a_{j}$ is the area, $r_{j}$ is the equivalence factor, $y_{j}$ is the yield factor, $E_{j}$ is the production of Bioproductive area $j(\mathrm{~kg})$, and $P_{j}$ is the world-average per unit yield of Bioproductive area $\mathrm{j}\left(\mathrm{kg} / \mathrm{hm}^{2}\right)$.

\subsection{Ecological Overshoot and Ecological Deficit}

A comparison of the Footprint and Biocapacity reveals whether existing natural capital is sufficient to support con- 
Table 3. The ecological footprint of biology resource of Ruyang County in 2012.

\begin{tabular}{|c|c|c|c|c|c|c|c|}
\hline Types & $\begin{array}{c}\mathbf{E F} \\
\text { Category }\end{array}$ & $\begin{array}{l}\text { Global Average } \\
\text { Yield }\left(\mathbf{k g} / \mathrm{hm}^{2}\right)\end{array}$ & Total Production & Total EF & $\begin{array}{c}\text { Per-Capital } \\
\text { EF }\end{array}$ & $\begin{array}{c}\text { Equivalence } \\
\text { Factor }\end{array}$ & $\begin{array}{l}\text { Per-Capital EF } \\
\text { after Adjustment }\end{array}$ \\
\hline \multicolumn{8}{|c|}{ Farm products } \\
\hline Grain & Area land & 2744 & 198186 & 72225.219 & 0.152693 & \multirow{6}{*}{2.8} & 0.427540 \\
\hline Legume & Area land & 1856 & 7886 & 4248.922 & 0.008982 & & 0.025152 \\
\hline Oilseed & Area land & 1856 & 10502 & 5658.405 & 0.011963 & & 0.033945 \\
\hline cotton & Area land & 1000 & 158 & 158 & 0.000334 & & 0.000935 \\
\hline tobacco & Area land & 1548 & 5876 & 3795.866 & 0.008025 & & 0.022470 \\
\hline vegetable & Area land & 18000 & 39663 & 2203.500 & 0.004658 & & 0.013044 \\
\hline Walnut & Forest & 3000 & 600 & 200 & 0.000423 & \multirow{3}{*}{1.1} & 0.000465 \\
\hline Chestnut & Forest & 3000 & 330 & 110 & 0.000233 & & 0.000256 \\
\hline Fruit & Forest & 3500 & 8767 & 2504.857 & 0.005296 & & 0.005825 \\
\hline \multicolumn{8}{|c|}{ Animal products } \\
\hline Pork & pasture & 74 & 9800 & 132432.432 & 0.279978 & \multirow[b]{4}{*}{0.5} & 0.139989 \\
\hline Beef & pasture & 33 & 1355 & 41060.606 & 0.086807 & & 0.043404 \\
\hline Mutton & pasture & 33 & 299 & 9060.606 & 0.019155 & & 0.009578 \\
\hline Poultry & pasture & 33 & 1786 & 54121.212 & 0.114419 & & 0.057209 \\
\hline aquatic products & Fisheries & 50 & 217 & 7482.759 & 0.015309 & 0.2 & 0.003164 \\
\hline
\end{tabular}

Note: EF-ecological footprint

sumption and production patterns. If the ecological footprint is less than the Biocapacity, which is called as Ecological overshoot(ER) and indicates that the development of society and human demand on the environment does not go beyond the bearing capacity of the environment. The development of the region is in a sustainable state. On the contrary, when the ecological footprint becomes larger than the Biocapacity, the ecological deficit(ED) appears in the region and the development of the region is unsustainable. The Ecological overshoot or ecological deficit can be obtained by (3).

$\mathrm{ED}(\mathrm{ER})=\mathrm{EC}-\mathrm{EF}=\mathrm{N}(\mathrm{ec}-\mathrm{ef})$

$\mathrm{N}$ is the population, ec is the per-capital Biocapacity, and ef is the per-capital ecological footprint.

\section{THE ECOLOGICAL FOOTPRINT OF THE RUY- ANG COUNTY}

The biological resource consumption includes farm products, animal products, forest products, and aquatic prod- ucts. According to the criteria about the global-average yield of the biological resource from FAO (Food and Agriculture Organization), the biological resource flows of the county in 2012 are all related to the Bioproductive area needed. Meanwhile, the ecological footprint of the trade is ignored because of the low volume of import and export (Table 3).

\subsection{The Ecological Footprint of Ruyang Energy Con- sumption}

Not only the biological products are contained in the people's consumption, the energy is also a essential part of human life. Therefore, it is necessary to assess the footprint of energy consumption consisting of the raw coal, fuel oil, gasoline, diesel and electricity. The biomass substitution approach, which calculates the area needed to replace fossil fuels with their energy equivalent in fuel wood, is used to calculate the energy footprint of the county. Fuel wood is chosen as the default replacement as it has been the historically dominant fuel for most societies and the primary fuel 
Table 4. The ecological footprints of energy of Ruyang County in 2012.

\begin{tabular}{|c|c|c|c|c|c|c|c|c|}
\hline Type & $\begin{array}{c}\text { EF Cate- } \\
\text { gory }\end{array}$ & $\begin{array}{c}\text { Global Average } \\
\text { Energy Footprint } \\
\left(\mathbf{G J} / \mathbf{h m}^{2}\right)\end{array}$ & $\begin{array}{c}\text { Converting } \\
\text { Efficient } \\
\text { (GJ/T) }\end{array}$ & $\begin{array}{c}\text { Consump- } \\
\text { tion (T) }\end{array}$ & $\begin{array}{l}\text { Total Foot- } \\
\text { print }\left(\mathrm{hm}^{2}\right)\end{array}$ & $\begin{array}{c}\text { Per-Capital } \\
\text { Footprint } \\
\left(\mathbf{h m}^{2}\right)\end{array}$ & E- Factor & $\begin{array}{c}\text { Adjusted } \\
\text { Per-Capital } \\
\text { EF }\left(\mathbf{h m}^{2}\right)\end{array}$ \\
\hline Raw cocal & Fossil fuel & 55 & 20.934 & 375595 & 142598.286 & 0.302231 & 1.1 & 0.332454 \\
\hline Gasoline & Fossil fuel & 93 & 43.124 & 14291 & 6626.721 & 0.014010 & 1.1 & 0.015411 \\
\hline fuel oil & Fossil fuel & 93 & 43.124 & 223 & 103.405 & 0.000219 & 1.1 & 0.000240 \\
\hline diesel & Fossil fuel & 93 & 42.705 & 21741 & 9983.327 & 0.021106 & 1.1 & 0.023217 \\
\hline electricity & built-up & 1000 & $3.6(1)$ & $62615(2)$ & 225.414 & 0.000477 & 2.8 & 0.001334 \\
\hline
\end{tabular}

Note: (1) has units of GJ/million kwh, and (2) has units of million kwh. The data in the Table 4 is from Luoyang statistical yearbook in 2013 and the sales volume of county oil company in 2012 .

Table 5. The Biocapacity of Ruyang County in 2012.

\begin{tabular}{|c|c|c|c|c|c|c|}
\hline Type & Area $\left.\mathbf{( h m}^{2}\right)$ & Per-Capital Area & Y- Factor & E-Factor & $\begin{array}{c}\text { Gross Per-Capital } \\
\text { Biocapacity }\left(\mathbf{h m}^{\mathbf{2}}\right)\end{array}$ & $\begin{array}{c}\text { Net Per-Capital } \\
\text { Biocapacity }\left(\mathbf{h m}^{2}\right)\end{array}$ \\
\hline \hline Arable & 33843.91 & 0.070789 & 1.66 & 2.8 & 0.329027 & 0.289544 \\
\hline Forest & 64367.31 & 0.136080 & 0.91 & 1.1 & 0.136216 & 0.119871 \\
\hline Pasture & 15145.55 & 0.032020 & 0.19 & 0.5 & 0.003042 & 0.002677 \\
\hline waters & 4323.17 & 0.009140 & 1 & 0.2 & 0.001828 & 0.001609 \\
\hline Built-up & 10605.39 & 0.022421 & 1.66 & 2.8 & 0.104213 & 0.091708 \\
\hline Unused & 4882.47 & 0.010322 & 1 & 0.12 & 0.001239 & 0.001090 \\
\hline Total & & & & 0.575565 & 0.506497 \\
\hline
\end{tabular}

Note: Y-factor-yield factor, E-factor-equivalence factor

Table 6. The ecological status of Ruyang County in 2012.

\begin{tabular}{|c|c|c|c|}
\hline Type & Per-capital Biocapacity & Per-Capital EF (hm $\left.{ }^{2}\right)$ & ED/ER (hm $\left.{ }^{2}\right)$ \\
\hline \hline Arable & 0.289544 & 0.537120 & -0.247576 \\
\hline Forest & 0.119871 & 0.006546 & 0.113325 \\
\hline Pasture & 0.002677 & 0.285202 & -0.282525 \\
\hline Waters & 0.001609 & 0.003164 & -0.001555 \\
\hline Built-up & 0.091708 & 0.001334 & 0.090374 \\
\hline Fossil fuel & 0 & 0.374016 & -0.374016 \\
\hline Unused & 0.001090 & 0 & 0.001090 \\
\hline Total & 0.506497 & 1.207382 & 0.700885 \\
\hline
\end{tabular}

the biosphere supplies without human modification. The rate of fuel wood used in this part is production equals the growth rate of fuel wood production for unit area.

\subsection{The Calculation of the Ruyang County Biocapacity}

The Bioproductive area of different categories is multiplied by the equivalence factor and yield factor after $12 \%$ of it subtracted for the biodiversity protection. Then by (2), the county Biocapacity in 2012 is obtained as illustrated in Table $\mathbf{5}$.

\subsection{The Calculation of Ecological Overshoot/Ecological Deficit}

By (3), the ecological status of Ruyang is determined as shown in Tabel VI

\subsection{Discussion}

As illustrated by the Table 6, in 2012, the per-capital ecological footprint of Ruyang county is $1.207382 \mathrm{hm}^{2}$, and percapital Biocapacity available is 0.506497 , so the ecological 
deficit of the county is 0.700885 , which is mainly from the consumption of the arable-land products, pasture products and energy. The ecological deficit of the county indicates that the regional development exceeds the bearing capacity of the nature. The proportion that each category of Bioproductive areas accounts for the county ecological footprint is calculated from Table 6. The proportion of arable land footprint and pasture footprint are $44.49 \%$ and $23.62 \%$ respectively, which is the major part of the county ecological footprint while the proportion of the forest footprint, fisheries footprint and built-up land footprint are much less, $0.54 \%$, $0.26 \%$ and $0.11 \%$ respectively. Therefore, the Bioproductive area for the grain and meat has high demand. Especially, with the rapid economic development, people's living standards are improved, the consumption of animal products, such as meat and milk, increases greatly.

From the perspective of energy consumption, the percapital ecological deficit of the fossil fuel land is $0.374016 \mathrm{hm}^{2}$, and the per-capital Bioproductive area for the raw coal consumption occupies $88.57 \%$ of the total ecological area of the energy consumption, which results from the fast developing heavy industry supported by the resource preponderance. However, such energy relying consumption structure has caused enormous pressure on the pasture ecology and sustainable development of the county.

Due to the abundant forest resource in the county with a forest coverage rate of $44.7 \%$, the per-capital ecological overshoot of forest is $0.113325 \mathrm{hm}^{2}$. With the development of social economy, more attention has been paid on the construction and protection of the ecological environment. For example, 'Grain for Green project' has been implemented in Henan province since 2002, and as the key county of forest, the forest area of Ruyang is expanded by $12,000 \mathrm{hm}^{2}$, which provides the county with effective ecological supply.

\section{CONCLUSION}

The comparison of the ecological footprint and Biocapacity reveals that the existing natural capital is not sufficient to support consumption and production patterns in the county. The pressure put on the ecological environment mainly comes from the high energy consumption, and high demand of arable land and pasture to satisfy people's increasing need of life and consumption.

To guarantee the safety of the regional ecosystem, and the sustainable development of the society, measures to decrease the regional ecological footprint and increase Biocapacity are shown as follow:

(1) Improve the agricultural science and technology to rise per unit biological yield and increase the land utilization efficiency. Then the ecological deficit of arable land will be reduced.
(2) To reduce the ecological footprint of energy consumption, it is essential to decrease the volume the fossil fuel consumption and optimize the energy consumption structure of the county by replacing the raw coal with electricity and gas, etc.

(3) Due to the 'Grain for Green project', the traditional forestry industry for which the timber trade is dominating is limited. However, with the improvement of people' life, the ecotourism is being greeted with increasing approval and developed rapidly in the world for its significant synthetically benefits and the nature of sustainable development. Therefore, the government of the county should take the advantage of the abundant forestry resource to develop the unique ecotourism industry in the region. By transforming the resources superiority as the economical superiority, the balance of regional ecological environment and economy development can be realized.

(4) To lessen the pressure of population upon the limited land resource, it is essential to control the regional population within the ecological tolerances.

(5) From the supply structure of the ecological footprint, it is found that the ecological supply of the arable land accounts for almost $57.06 \%$, which indicate that the regional Biocapacity relies largely on arable land. Hence, the occupation of the arable land has to be controlled and reduced by the rational use of land resources during city construction and development.

\section{CONFLICT OF INTEREST}

The authors confirm that this article content has no conflict of interest.

\section{ACKNOWLEDGEMENTS}

Declared none.

\section{REFERENCES}

[1] W. E. Rees, "Ecological footprint and appropriated carrying capacity: what urban economics leave out", Environment and Urbanization , vol. 4, no. 2, pp. 121-130, 1992.

[2] R. Costanza, R. Darge, and R. Groot, "The value of the world's ecosystem services and natural capital", Nature, vol. 38, no. 7, pp. 253-260, 1997.

[3] K. Yang, Y. Yang, and J. Chen, "Overview of the ecological footprint model", Advance in Earth Scinenc, vol. 15,n o. 6, pp. 630636, 2000.

[4] M. Wackernagel, and P. Bello, "Ecological footprints of nations", In: International Council for Local Environment Initiatives, Toronto, Canada, 1997, pp. 10-21.

[5] M. Wackernagel, L. Onisto, and P. Bello, "National natural capital accounting with the ecological footprint concept", Ecological Economics, vol. 29, no. 3, pp. 375-390, 1999.

\footnotetext{
Received: June 10, 2015

Revised: July 29, 2015

Accepted: August 15, 2015

(C) Jun and Jinxin; Licensee Bentham Open.

This is an open access article licensed under the terms of the (https:/creativecommons.org/licenses/by/4.0/legalcode), which permits unrestricted, noncommercial use, distribution and reproduction in any medium, provided the work is properly cited.
} 